\title{
In Search of Confianza: A Qualitative Analysis of Salvadoran Parents' Experiences in U.S. Urban Schools
}

\author{
Dr. Ingrid T. Colón \\ U. S. A. \\ Dr. Marlon James \\ Texas A\&M University \\ U. S. A. \\ Mahjabin Chowdhury \\ Texas A\&M University \\ U. S. A. \\ Dr. Amy Rector-Aranda \\ Texas A\&M University \\ U. S. A. \\ Dr. Miguel Burgess Monroy \\ Texas A\&M University \\ U. S. A.
}

\begin{abstract}
This qualitative study of six recently arrived parents from El Salvador who have been in the U.S. for no longer than a year explores their experiences in U.S. schools and offers recommendations for actualizing an ethos of humanitarianism in schools. In particular, the study addresses the perspectives of recently arrived Salvadoran parents about their children's education and how can schools effectively collaborate with parents to support the emotional, social, cultural, and educational needs of their children. The study drew on testimonios to learn about Salvadoran parents' perspectives about their children's education to improve the services their children need in schools.
\end{abstract}

KEYWORDS: Social Justice, Immigrant Community, Family Engagement, Recently Arrived Salvadoran Families, Latinx

\footnotetext{
Literature Review

Methodology

Findings

Discussion

Conclusion

References

Author Contact
} 
Since its inception, the United States (U.S.) has been a country of immigrants, yet present national dialogue and federal policies are cultivating an anti-immigrant ethos in the country. Federal policies have long sought to reduce immigration among the Latinx population in particular (Migration Policy Institute, 2015). The term Latinx is an inclusive term that reflects the diversity of gender identities among people from Latin America (Scharrón-del Río \& Aja, 2015). Latinx immigrants (e.g., Cuban, Dominican, Puerto Rican, Mexican, Central or South American) represent $53 \%$ of all U.S. immigrants (U.S. Census Bureau, 2010) and form a significant part of the unique diversity of this country. Due to a recent shift in federal policy, more than 200,000 Salvadorans were jeopardized by the revoking of their Temporary Protected Status (TPS), which had allowed Salvadoran migration to the U.S. in the wake of the 2001 earthquakes. Although in October 2019 the current administration extended protections from deportations to Salvadorans with TPS, Salvadorans remain in constant fear and uncertainty. If this policy shift remains the same, they will have until January 2021 to achieve residency or leave the country. The consequences for communities and schools that serve Salvadoran youth are complex and urgent. Many school-aged Salvadorans were born in the U.S. or came to the country so young that the U.S. is their home. How can schools more effectively collaborate with parents to support the emotional, social, cultural and educational needs of Salvadoran learners? The present article discusses the experiences of Salvadoran parents in U.S. schools and offers recommendations for actualizing an ethos of humanitarianism in schools.

\section{Literature Review}

The following literature review includes current research related to the unique cultural disconnections between many Latinx families and schools. Then, we consider culturally responsive approaches to collaborating with Latinx families.

The review of literature confirms that there is a need on the part of U.S. schools to better understand Latinx families in order to better serve them. The trend in U.S. schools has been to assimilate immigrants by subtractive schooling (Valenzuela, 1999). This belief devalues the diversity that Latinx immigrants bring to U.S. schools, and teacher (mis)preparation leaves educators certified but unprepared to support the needs of bilingual learners (Balderrama, 2001). For example, Villalba, Brunelli, Lewis, and Orfanedes (2007) conclude in their study that many Latinx parents had positive experiences in schools related to the quality of after-school programs and hiring of bilingual staff but had negative experiences when teachers disrespected children by not valuing their cultural heritage. Parents identified a need for schools to incorporate the teaching of valores, family values and good manners, into classroom activities. Moreover, Zentella (2005) posits that Latinx parents consider the classroom as an extension of the home and expect teachers to maintain and extend their home values to 
schools. In fact, the Spanish term maleducados does not refer to children who lag academically, but to those who are "disrespectful of self, family and others" (Sheets, 2005, p. 206). The present research is reflective of JimenezCastellanos, Ochoa, and Olivos' (2016) work, which advocates for a transformative parental engagement model that fosters mutual learning by educators and families within the context of the complex social, political, and economic systems that limit Latinx parental engagement. However, we seek to apply their work, which is largely focused on Mexican parental engagement, to under-researched Latinx populations such as Salvadorans.

While cultural disconnections abound, researchers have explored various ways to create robust support systems between classrooms and Latinx families. To foster more supportive collaboration between families and schools, several cultural insights should be considered. First, one source contributing to the lack of understanding between Latinx parents and teachers is that Latinx parents perceive teachers as experts (Gallo \& Wortham, 2012; Zentella, 2005). Therefore, in some ways, many Latinx don't advocate for themselves in schools because it is not culturally appropriate, but U.S. teachers consider advocacy as a sign of parental care and involvement. The implications of this disconnect are exemplified by Gallo and Wortham's (2012) research on a dozen Mexican immigrant parents who had limited use of English, but cared deeply for their children's education. Despite this fact, teachers expected the parents to extend the English learning opportunities of the students through helping them with homework assignments written only in English (Durand, 2011; Gallo \& Wortham, 2012; Zentella, 2005).

The second approach to building stronger ties between Latinx families and schools is highlighted by Gutierrez and Rogoff's (2003) research advocating that schools take a cultural repertoires approach. This approach contrasts with the deficit perspective held by many teachers and encourages schools to identify and integrate the funds of knowledge within Latinx families and communities (Moll, Amanti, Neff, \& Gonzalez, 1992). These asset-based approaches emphasize transferring the experiences and strengths of Latinx families into the classroom to support their children's learning, development, and achievement. For instance, the researchers provided several examples of how parents and community members volunteered as community experts during lessons that highlighted their professional skills, hobbies, and cultural traditions.

Thirdly, rethinking Latinx parent-teacher collaboration relies on building confianza, trust, which describes communication and understanding between parents and teachers (Tschannen-Moran, 2001; Zentella, 2005). Schools can begin by acknowledging that most Latinx parents do engage with their children's education, but are too often seen as uninvolved. An example is Mulhern's (2007) case study about a Mexican immigrant family with a son attending kindergarten, which found that both parents valued and supported education. The mother listened to her son reading and answering questions about reading and writing. She talked with her son about his school experiences, supervised his homework completion, worked on writing and reading activities with him, and made books 
available for him at home. This illustrates the need for teachers to reach out to parents to learn about their home lives, which in turn will develop much-needed confianza.

Finally, Durand (2011) recommends that schools can improve partnerships by building collaborative spaces in schools that offer welcoming environments for Latinx parents to dialog with teachers. However, as Cavanagh, Vigil, and Garcia (2014) and Jasis and Ordoñez-Jasis (2012) assert, these collaborative spaces must empower parents by focusing on respect for and understanding of Latinx parents and utilizing their expertise in school decisions. Parents need spaces where they can feel comfortable sharing their opinions so that they can feel they are valued advocates for their children's education.

Latinx families face pressures to conform to Eurocentric cultural worldviews in education. This form of educational oppression limits the use of cultural gifts socialized into youths by families, further compounding an already difficult situation. Additionally, there remains a disconnection between researchbased solutions and their use in schools to respond to the unique needs of Latinx learners (Gallo \& Wortham, 2012; Moll et al., 1992; Mulhern, 1997; Olivos, 2004; Quiñones \& Marquez Kiyana, 2014; Zentella, 2005). Finally, while in this review we found ample research on the topics of cultural disconnections and cultural responsiveness for Latinx families, it was mostly focused around the experiences of Mexican immigrant communities. There is a need to explore how recently arrived immigrants from El Salvador experience schooling in the U.S. and support their children's education.

\section{Methodology}

This qualitative study (Denzin \& Lincoln, 2005) features the experiences of six recently arrived parents from El Salvador who have been in the U.S. for no longer than a year. We used testimonio as the methodology to explore the perspectives these parents have about their children's education. Testimonio is "both a product and process" (Delgado Bernal, Burciaga \& Carmona, 2012, p. $365)$; it is "a methodological tool that supports critical reflection, healing, and collective memory through the act of testimoniando, providing one's testimonio, to testify" (Pérez Huber \& Cueva, 2012, p. 396). Historically, the Latin American approach of testimonio was used during times of war to gather stories from oppressed people. This approach has a direct connection with recently arrived Salvadorans, because Salvadorans are still experiencing the aftermath of their civil war and were granted temporary protected status in the U.S. Testimonio as a methodological framework acknowledges this important context, which is critical for understanding the urgent nature of parent concerns we explore using the methods that follow.

\section{Data Collection}


All participants identified as Salvadorans and have biological children between the ages of 4-17 years old enrolled in the District of Columbia Public Schools (DCPS) system (see Table 1). This study addresses the following research questions:

- What are the perspectives of recently arrived Salvadoran parents concerning their children's education?

- How can schools support the emotional, social, cultural, and educational needs of Salvadorans?

Participants were recruited through the snowball sampling method (Patton, 1990), which consists of personal referrals from participants. The data were collected through semi-structured interviews (Fontana \& Frey, 2000), each lasting between 20 and 30 minutes. All interviews were audio-recorded with participant permission, and pseudonyms were assigned to each participant.

Recognizing the geographical and small sample size limitations, our goal with this study was only to learn from six participants in a specific context and setting. The findings from this study can be used as a resource for educators and stakeholders to modify the services they offer to recently arrived Salvadoran parents; however, we recognize the limitation that our findings only directly relate to the public schools in Washington, D.C. Therefore, we do not intend to draw generalized conclusions and implications to greater populations of other recently arrived immigrants in different geographical areas and settings.

\section{Participants}

In this study there were a total of six participants; five were female and one male. Their number of children ranged from one to three, and the range of time they had lived in the U.S. was three to twelve months. In the following section, we provide a description of each of our participants to better understand the perspectives they brought to our study.

Camila is a single mom with an eight-year-old daughter named Sofia who is in the third grade in a public school. Camila came to the U.S. to provide a safer environment and better education for Sofia and to support her adult sons, her parents, and her siblings in El Salvador. Camila is a registered nurse in El Salvador, but works in a Mexican restaurant in the U.S. She also attends weekly ESL classes.

Vilma is a single mother of Julio who is enrolled in the fifth grade in a public school. She brought Julio to the U.S. to ensure a safe and secure future and a better education. She works at a seasonal cleaning company and attends ESL classes with Camila.

Sonia, along with her husband, Braulio, have three children who all attend public schools in DCPS: a ninth grader, a third grader, and a four-year-old. They 
came to the U.S. to escape the dangers presented by maras, gangs, and to provide better opportunities for their children. Sonia attended school up to sixth grade in El Salvador. She works very late in an Italian restaurant and picks up extra time cleaning houses in the morning.

Mélida has three children with her husband, Carlos; all three children attend public schools in DCPS. They have two ninth graders and a fifth grader. They came to the U.S. to raise their children in a safe environment and to give them a better future. Mélida currently does shift work in an Italian restaurant.

Lydia has two children with her husband, Marcos. Their adult daughter lives in El Salvador and their 16-year-old son attends public school in DCPS. Lydia attended school up to the eighth grade in El Salvador and now attends English classes every morning.

Nelson has three children with his wife, Ana. All of their children attend public school in DCPS. They have a ninth grader, a third grader, and a preschooler. Nelson brought his family to the U.S. to escape from the violence in El Salvador and to provide a better future for his children. Nelson completed high school in El Salvador and currently works in a Mexican restaurant and plays in a mariachi band.

Table 1. Participant Demographics

\begin{tabular}{|c|c|c|c|c|c|c|}
\hline $\begin{array}{l}\text { Participant } \\
\text { Number }\end{array}$ & Pseudonym & Gender & $\begin{array}{l}\text { Number } \\
\text { of } \\
\text { Children } \\
\text { in the } \\
\text { U.S. }\end{array}$ & $\begin{array}{c}\text { Ages } \\
\text { of } \\
\text { Children }\end{array}$ & $\begin{array}{c}\text { Department } \\
\text { of } \\
\text { El } \\
\text { Salvador }\end{array}$ & $\begin{array}{c}\text { Months } \\
\text { Living } \\
\text { in the } \\
\text { U.S. }\end{array}$ \\
\hline 1 & Camila & Female & 1 & 8 & $\begin{array}{c}\text { San } \\
\text { Miguel }\end{array}$ & 3 \\
\hline 2 & Vilma & Female & 1 & 10 & $\begin{array}{c}\text { San } \\
\text { Vicente }\end{array}$ & 4 \\
\hline 3 & Sonia & Female & 3 & $\begin{array}{c}4,8 \\
14\end{array}$ & $\begin{array}{c}\text { San } \\
\text { Miguel }\end{array}$ & 11 \\
\hline 4 & Mélida & Female & 3 & $\begin{array}{c}10,16 \\
17\end{array}$ & $\begin{array}{c}\text { San } \\
\text { Miguel }\end{array}$ & 11 \\
\hline 5 & Lydia & Female & 1 & 15 & $\begin{array}{c}\text { La } \\
\text { Libertad }\end{array}$ & 12 \\
\hline
\end{tabular}




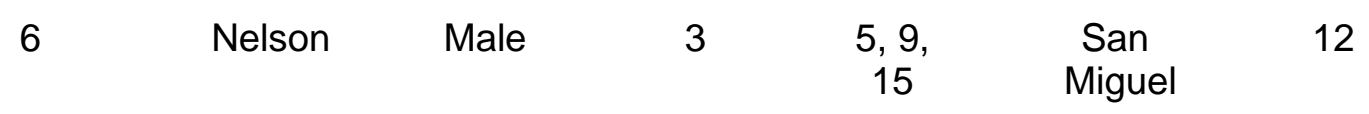

\section{Data Analysis}

According to Creswell (1994), the data analysis process requires researchers to develop categories and interact with the data. At the same time, the researcher needs "to be open to possibilities and see contrary or alternative explanations for the findings" (Creswell, 1994, p. 153). With that purpose in mind, after the data collection, the interviews were transcribed and uploaded to Dedoose, a web-based software for data analysis. This program allows researchers to code line-by-line through transcripts, organize codes into main and sub-codes, and draw comparisons within and across transcripts. We used an inductive analysis approach (Lincoln \& Guba, 1985) to generate themes within each transcript independently, and then compared across all transcripts to find common meta-themes, which were then regrouped into emergent themes. We identified and shared direct quotes from participants' interviews that represented the emergent themes of the study.

Throughout this study, we wanted to make sure that the participants' voices were represented. For this reason, we did not literally translate participants' quotes from Spanish to English because pivotal understandings can get lost during the translation process. As Delgado Bernal, Burciaga, \& Carmona, (2012) suggest, "One must be cautious to translate conceptually rather than literally because in translating particular terms, nuances get lost, and we run the risk of reproducing language marginalization" (p. 365). Direct quotes were conceptually translated from Spanish to English and their meaning and implications were interpreted using reflexión, reflexivity, which Lincoln and Guba (2000) describe as "the process of reflecting critically on the self as a researcher, the "human as instrument" (p. 183). We believe that this methodological approach is humanizing and aligns with our shared commitment to equity research.

In the next section, we present findings gathered from our participants' perspectives on how schools can better serve recently arrived Salvadoran parents and their children. For purposes of legitimizing and elevating our participants' voices, we intentionally do not intertwine their perspectives with the literature we reviewed above. We have agreed to use our participants' testimonios as valid, authentic, and critical analyses that help identify gaps in current research that has historically not included their points of view. 


\section{Findings}

In this study, each participant represented a piece of the rich and vibrant Salvadoran community in Washington, D.C. All of our participants were excited to share their testimonios, testimonies, about the perspectives they have regarding their children's education with educators and stakeholders to improve the services their children need in schools. In this section, we explore the two previously mentioned research questions:

1. What are the perspectives of recently arrived Salvadoran parents concerning their children's education?

2. How can schools support the emotional, social, cultural, and educational needs of Salvadorans?

The following four themes emerged from an analysis of the data: (a) communication, (b) understanding, (c) counseling, and (d) information.

\section{Communication}

Building relationships. The first sub-theme that emerged was the importance of building confianza, communication and understanding between parents and teachers (Tschannen-Moran, 2001; Zentella, 2005). When asked about what advice parents would give teachers to improve the relationships between teachers and parents ("Que traten de conocer más a los padres?"), Vilma responded that teachers need to try harder to meet their students' parents in person to get to know them better. She also suggested that teachers should meet and interact with parents once a month or every three months to ensure that parents are aware of what their children are doing in school. Vilma felt that she was not offered enough opportunities to meet with Julio's teachers unless she reached out to them. Moreover, Vilma suggested that teachers become more interested in learning about their students' behavior at home. Vilma thought that this communication should be mutual, because she was also interested in knowing about how her son is behaving at school. She expressed that this communication is necessary because she was not frequently informed about her son's behavior or academic performance.

Similarly, Camila shared that she wanted to know what and how her daughter Sofia is doing in school on a daily basis. She described that she had to take the initiative to ask teachers about how Sofia is doing at school because otherwise she would not receive that information. Moreover, she shared that when she asked Sofia's teachers about how Sofia is doing in school, they only gave her good feedback. However, Camila also wanted to know about the areas in which she needs to give additional support to Sofia at home. It is important to note that participants reported receiving some communications from teachers but only in English. Thus, confianza, communication and understanding, requires 
acknowledging when language or culturally specific parenting styles require new approaches to connecting with parents.

Strengthening collaboration. The second sub-theme that emerged was the importance of improving collaboration between parents and teachers through focusing more on what parents need. "Más enfoque en los papás." Camila suggested an orientation for parents focusing on parents' needs to better support their children at home. She thinks this could be an opportunity for teachers and parents to come together, get to know each other, and promote mutual communication.

Camila, Lydia, Vilma, and Nelson indicated having challenges due to the lack of communication about school policies and expectations for parents and students. For example, Camila explained that parents need more information about the daily activities in schools. Camila described that she felt misinformed about the day-to-day processes and operation of Sofia's school. Lydia and Vilma also felt concerned that their children were telling them that they are not eating at school. They stated that they did not even know about what the school served their students to eat during breakfast and lunchtime.

Additionally, Nelson, a father of three, stated that he was not aware of the consequences for students who are not following the rules of the school his daughter, Maria, attends. Nelson recalled seeing many students not following school rules such as the dress code and observed students smoking outside of the school. He wondered about how much the school is enforcing rules and if there are any consequences for those students who do not follow school policies. Nelson expressed this concern because he did not want Maria to stop following the school's expectations or become part of groups of students who are causing trouble. Lydia also expressed her concern about not knowing about school issues such as fights between students that she never hears about from any teacher or administrator.

Moreover, all participants agreed that there is not enough support to help their children with homework. In fact, all of the participants responded that the homework that their children bring home is only in the English language. All participants noted that the instructions for homework assignments are never in Spanish and that they had difficulties understanding what they needed to do to help their children. Sonia requested additional homework instructions in Spanish to better help her children at home. Sonia stated, "Que [los maestros] nos mandaran una copia [de la tarea] en español o por lo menos un ejemplo." Sonia suggested that teachers should send copies of the homework instructions to parents in Spanish or at the very least send an example of what children need to do in their homework so parents have a better understanding of the assignments.

Camila even wondered how other recently arrived Salvadoran parents who do not know how to read and write in Spanish and who do not have any resources at home, such as dictionaries or electronic translators, were able to support their children academically. Camila expressed her concern about how teachers are unaware that some parents are barely able to write their own name 
and know only basic academic skills. Camila explained that even though she has academic degrees in nursing in El Salvador she struggled to help Sofia with her homework and wondered how parents without a formal education can possibly help their children with homework. She stressed that teachers need to keep in mind that not all parents have the abilities to support their children at home. Similarly, Sonia stated that her husband, Braulio, was able to help her children with homework because he completed high school in El Salvador; however, it was still difficult because he did not speak English.

To summarize, the participants' sentiments confirm Zentella's (2005) conclusion that Latinx parents desire close connections between home and school. Yet, the cultural mismatches between teachers and parents resulted in poor communication and parents feeling uninformed and having to assume more assertive roles in their children's education that went beyond their culture norms.

\section{Understanding}

The hardships of immigrating to the U.S. The first sub-theme that emerged was the schools' lack of understanding of the Latinx immigrant experience. Sonia wanted teachers to understand that "Uno pasa cosas feas para llegar aquí," that many Salvadoran immigrants experience great danger getting to the U.S. This is somewhat paradoxical because, as Vilma noted, "Porque estamos fuertes y queremos sobresalir, llegamos donde estamos pero en ocasiones, nos ven de menos. Con mucho racismo para con nosotros." Although Salvadoran immigrants show that they are strong and resilient by the very fact that they have made it to the U.S., they are often looked down upon and treated with racism. While all of the participants wanted teachers to understand the hardships they experience arriving to the U.S., Nelson made it clear that he is "muy agradecido," very thankful, that he is able to be in the U.S. He stated, "Mi decisión de vivir acá...es para darle un mejor futuro a mis hijos;" his decision to live in the U.S. was to give his children a hope for a better future.

The hardships of learning English. The second sub-theme that emerged was the desire for teachers to be more patient with students and families learning English. Lydia expressed, "Que me le tuviera un poco más de paciencia;" she wishes teachers to be more patient with her child. Lydia recalled an especially unsettling event that occurred during a parent-teacher meeting. She stated,

Hubo una profesora que ella no habla nada en español...le habló al niño como muy feo, él tenia como cinco meses de estar estudiando...le gritó bien feo y le dijo que aprendiera el inglés y le dijo que ella no lo quería en su clase... mira me dió lástima el niño...en ese momento, se le metió que ya no quería ir a la escuela. 
As Lydia explained, there was a teacher who did not speak any Spanish and who spoke to her son in a very disrespectful manner because her son did not speak English when he only had been studying English for five months. This teacher yelled at her son in an ugly way and told him that if he did not learn English, she didn't want him in her class. Lydia shared that due to this interaction her son didn't want to go to school anymore. This reveals the unreasonable expectation that some teachers and staff may hold that children need to learn English much quicker than logically is possible.

The participants also expressed the desire that teachers and staff be able to speak at least some Spanish. Vilma noted that she always had to seek out the school secretary to translate since her child's teacher did not speak any Spanish. The other participants stated that they also had to seek other bilingual teachers or staff members at times to be able to communicate with their child's teacher. Lydia shared that sometimes teachers relied on another student to translate both informally and during parent-teacher meetings.

\section{Counseling}

When asked about suggestions for services needed in schools to better serve recently arrived Salvadorans, Camila stated that therapy is needed not only for children but also for parents who just arrived to the U.S. from El Salvador due to the violence they have witnessed or experienced. Camila's vivid account about the unfortunate issues that El Salvador is facing includes murders, gangs, and extortions. She expressed the need for Salvadoran parents to receive some type of counseling because it is likely that parents were more affected and traumatized than their children. Participants like Camila and Mélida shared that parents try to shield their children as much as possible from the reality they are living, and as a result they do not take care of their own traumas.

Sonia suggested that schools need to have therapists available to ask children why they and their parents came to the U.S. and learn about the different reasons why Salvadoran come here. Sonia explained that this is important because schools need to know that not all immigrants come to the U.S. based on personal preference, but instead may have decided to immigrate for reasons of distress.

All six participants explained that the most important reason for leaving El Salvador was due to the violence that the country is experiencing. For example, Mélida expressed that her urgency to leave was to provide a safer environment for her children. Mélida expressed that she and her family spent nights at a neighbor's house because they did not feel safe in their own home. Like Mélida who needed help from a neighbor to find a safe place to spend nights, Sonia had to rely on her neighbor to pick up her children from school because of extortion calls that she received from mareros, gang members, telling her to give them 
money or they would go to her children's school and kill them.

All participants shared similar testimonios about the difficult situations they had lived through in El Salvador. They all reflected on the dangerous living conditions they had experienced that included a consistent fear of gun violence and the inability to provide their children a peaceful life. Participants agreed that they felt safer in the U.S., and did not care about leaving their homes and their loved country in search for "más seguridad," more security. Mélida and Sonia, for instance, explained that it did not matter to them that now they live in a small crowded apartment because it is a safer life and the lives of their children are what matters the most.

Each participant expressed a similar sentiment of uncertainty and always feeling unsafe in El Salvador while raising their children. Participants shared traumatic experiences from their living conditions in El Salvador that motivated them to come to the U.S. in search for safety. The testimonios from Camila, Mélida, and Sonia underscored the need of counseling for recently arrived Salvadoran parents and their children to heal from the horrific experiences they lived through in El Salvador.

\section{Information}

Resources for children. Looking back on their experiences in El Salvador, participants found a need for counseling for children as well as adults. Looking forward to their children's futures in the U.S., they found a greater need for information for their children. Vilma expressed the need for "talleres para que [los estudiantes] vayan poniéndose un objetivo de lo que ellos quieren ser cuando sean grandes," meaning that parents want workshops for their children that can help them set goals for what they want to be when they grow up.

All the participants in the study expressed their desire for their children to take advantage of the increased educational opportunities available in the U.S. Sonia expressed a desire for schools to provide students with more information regarding identifying and avoiding gangs. She noticed that the same violent gangs that exist in El Salvador such as La Mara Salvatrucha (MS-13) also exist in the U.S. The participants were concerned that the gangs could influence their high school age children and wanted their children to stay away from them at any cost. Sonia expressed, "Nosotros lo hemos vivido en carne propia," meaning that they had experienced in their own lives the destruction that gangs can create.

Also, the parents expressed the need for the schools to function as a center of information in part because it's difficult for many of the parents to support their children by finding and providing the information themselves because of their own varying levels of literacy in English. Instead they find other 
ways to support their children. For example, Mélida stated she was unable to help her children with their homework very much because she doesn't speak English. However, she supported her children by making sure they only have to focus on school. She stated,

Que yo no los pongo, les digo yo, a hacer nada más que trabajen, pues en el estudio, que es lo que les va a servir a ellos y como pues así, yo ya les tengo ahí la comida preparada.

Mélida explained that she tells her children that she will always have their food ready for them because she only wants them to focus on their studies, which is the most important thing for their futures. Nelson echoed Mélida when he said, "Yo quiero que ellos sepan que mi esposa y yo estamos aquí para apoyarlos en lo que nosotros podamos;" he wants his children to know that he and his wife are there to support them in everything they can.

Mélida, Sonia, and Lydia did not have a formal education and did not know any English, but they all wanted their children to know that they have their moral support and encouragement. For example, Lydia stated,

Pues yo le digo todos los días que estoy muy orgullosa de él, viera que inteligente me ha salido no por ser mi hijo verdad, pero si, y eso que yo lo crié sola en El Salvador.

Lydia tells her son every day that she is very proud of him and that he has turned out to be such an intelligent son even though she had raised him alone in El Salvador.

\section{Discussion}

Above we describe the four themes that emerged from our analysis of the data: (a) communication, (b) understanding, (c) counseling, and (d) information. Our study contributes to the extant literature by addressing both the perspectives that recently arrived Salvadoran parents have concerning their children's education, and the support that schools need to provide to meet the emotional, social, cultural, and educational needs of Salvadorans. Prior to this study there was a lack of research around the perspectives that recently arrived Salvadoran parents have about their children's education. Additionally, there was a lack of research around the ways schools can provide support to better serve the emotional, social, cultural, and educational needs of Salvadorans.

Although the extant literature (Cavanagh et al., 2014; Gallo \& Wortham, 2012; Gurrola et al., 2016; Jasis \& Ordoñez-Jasis, 2012; Moll et al., 1992; Mulhern, 1997; Olivos, 2004; Quiñones \& Marquez Kiyana, 2014; Zentella, 2005) has provided insights for schools to help Latinx parents and students navigate schools' expectations and build collaborative relationships, our study indicates that the literature has not yet addressed the fact that recently arrived Salvadorans need specific resources to facilitate their transition to an unknown 
culture once in the U.S.

This study filled these gaps in the existing literature and answered the research problem of how to better serve the needs of recently arrived Salvadoran students and their parents to build and sustain collaborative relationships in U.S. schools. We did this by addressing the unique perspectives that recently arrived Salvadoran parents have about their children's education and how schools can provide the supports to meet the emotional, social, cultural, and educational needs of Salvadorans.

Findings also demonstrate the need for understanding recently arrived Salvadoran parents and their children in U.S. schools. Findings moved beyond the extant literature, which lacks research about understanding recently arrived Salvadoran parents' hardships of immigrating to the U.S. and learning a new language in schools. In addition to showing respeto y confianza (TschannenMoran, 2001; Zentella, 2005) to build and sustain collaborative relationships with recently arrived Salvadoran parents, our results suggest that educators need to focus on understanding these parents.

Our findings also showed the need for counseling in schools for both parents and students due to the hardships that some recently arrived Salvadoran parents experienced in El Salvador and on their journeys to the U.S. Understanding the challenges that recently arrived Salvadoran parents and students experience advances the research about creating school spaces for empowerment (Cavanagh et al., 2014; Durand, 2011; Jasis \& Ordoñez-Jasis; 2012; Olivos \& Quintana de Valladolid, 2005) because it provides another way to empower recently arrived Salvadoran parents and students through counseling services. Our findings addressed the fact that some recently arrived Salvadoran parents and their children may have gone through traumatizing experiences and that they can benefit from counseling services to help them overcome these experiences.

Similarly, findings indicate that recently arrived Salvadoran parents can also benefit from school-provided information about resources (e.g., workshops for their children) so that parents can better transition to a life in this country, contributing to the extant research about rethinking Latinx parent-teacher collaboration (Doucet, 2011; Pacheco \& Gutiérrez, 2009; Tschannen-Moran, 2001; Zentella, 2005) because it emphasized the unique services and resources that recently arrived Salvadoran parents need in schools. Our research indicates that these parents felt more comfortable interacting with educators when schools offered them unique services and considerations. However, recently arrived Salvadoran parents also wanted educators to move beyond just offering these services and instead to initiate closer relationships with parents to learn about what they need. 


\section{Conclusion}

Overall, the parents in this study provided key recommendations for how to promote confianza in U.S. schools. Specifically, they recommended that schools must improve communication with parents by helping them understand the overall functions of U.S. schools. In order to do so, they suggested that schools must provide culturally and linguistically responsive communicative tools and services that can help build stronger parent-teacher relationships and avoid misunderstandings. Moreover, they suggested that schools should show more understanding about students and families' journeys to the U.S. and the challenges associated with learning a new language. In particular, schools should offer counseling for parents and children due to the traumatizing experiences they may have had in EI Salvador or in their journeys to the U.S. By improving communication with parents and reconsidering views on Salvadoran parental engagement, families will be seen as assets to the education of children rather than impediments to increase their future aspirations and educational endeavors.

This research was undertaken to explore the experiences of recently arrived Salvadoran parents in U.S. schools during a critical time of uncertainty and pervasive insensitivity to immigrants in the U.S. Research abounds concerning the experiences of Mexican parents and children (Gallo \& Wortham, 2012; Gurrola, Ayón \& Moya Salas, 2016; Moll et al., 1992; Mulhern, 1997; Zentella, 2005), but too little has been done to better understand the experiences of immigrants from Central America in U.S. schools. This qualitative analysis brought to light and life the harsh realities that Salvadoran parents and their children face to live in America, and the continuing struggles of U.S. schools and teachers to communicate responsively, foster confianza, and collaborate with recent Salvadoran immigrant families.

\section{References}

Balderrama, M. V. (2001). The (mis) preparation of teachers in the Proposition 227 era: Humanizing teacher roles and their practice. The Urban Review, 33, 255-267.

Banks, J. A. (Ed.). (1996). Multicultural education: Transformative knowledge and action. New York, NY: Teachers College Press.

Cavanagh, T., Vigil, P., \& Garcia, E. (2014). A story legitimating the voices of Latino/Hispanic students and their parents: Creating a restorative justice response to wrongdoing and conflict in schools. Equity and Excellence in Education, 47(4), 565-579.

Creswell, J. W. (1994). Research design: Qualitative \& quantitative approaches. Thousand Oaks, CA: Sage Publications, Inc. 
Delgado Bernal D., Burciaga, R., \& Carmona, J. F. (2012). Chicana/Latina testimonios: Mapping the methodological, pedagogical, and political. Equity and Excellence in Education, 45(3), 363-372.

Denzin, N., \& Lincoln, Y. (2005). The Sage handbook of qualitative research. Newbury Park, CA: Sage

Doucet, F. (2011). Parent involvement as ritualized practice. Anthropology \& Education Quarterly, 42(4), 404-421.

Durand, T. M. (2011). Latina mothers' cultural beliefs about their children, parental roles, and education: Implications for effective and empowering home-school partnerships. Urban Review, 43(2), 255-278.

Fontana, A., \& Frey, J. H. (2000). The interview - from structured questions to negotiated text. In N. Denzin \& Y. Lincoln (Eds.), Handbook of qualitative research ( $2^{\text {nd }}$ ed., pp. 645-672). Thousand Oaks, CA: Sage Publications.

Gallo, S., \& Wortham, S. (2012). Sobresalir: Latino parent perspectives on new Latino diaspora schools. International Journal of Multicultural Education, 14(2), 1-17

Gurrola, M., Ayón, C., \& Moya Salas, L. (2016). Education and hopes in an antiimmigrant environment: The perspectives of first and second-generation youth and parents. Journal of Family Issues, 37(4), 494-519.

Gutiérrez, K. D., \& Rogoff, B. (2003). Cultural ways of learning: Individual traits or repertoires of practice. Educational Researcher, 32(5), 19-25.Jasis, P. M., \& Ordoñez-Jasis, R. (2012). Latino parent involvement: Examining commitment and empowerment in schools. Urban Education, 47(1), 6589.

Jiménez-Castellanos, O., Ochoa, A. M., \& Olivos, E. M. (2016). Operationalizing transformative parent engagement in Latino school communities: A case study. Journal of Latino-Latin American Studies (JOLLAS), 8(1), 93-107. Retrieved from http://ezproxy.library.tamu.edu/login?url=http://search.ebscohost.com/login .aspx?direct=true\&db=tsh\&AN=115251016\&site=eds-live

Lincoln, Y. S., \& Guba, E. G. (1985). Naturalistic inquiry. Beverly Hills, CA: Sage.

Migration Policy Institute. (2015). Unaccompanied child migrants in U.S. communities, immigration court, and schools. [Policy Briefs]. Washington, DC: S. Pierce. Retrieved from http://www.migrationpolicy.org/research/ unaccompanied-childmigrants-us-communities-immigration-court-andschools

Moll, L., Amanti, C., Neff, D., \& Gonzalez, N. (1992). Funds of knowledge for teaching: Using a qualitative approach to connect homes and classrooms. Theory in Practice, 31(2), 132-141. 
Mulhern, M. M. (1997). Doing his own thing: A Mexican-American kindergartner becomes literate at home and school. Language Arts, 74(6), 468-476.

Olivos, E. M. (2004). Tensions, contradictions, and resistance: An activist's reflection of the struggle of Latino parents in the public school system. The High School Journal, 87(4), 25-35.

Olivos, E. M., \& Quintana de Valladolid, C. E. (2005). Entre la espada y la pared: Critical educators, bilingual education, and education reform. Journal of Latinos and Education, 4(4), 283-293.

Patton, M. (1990). Qualitative evaluation and research methods. Beverly Hills, CA: Sage.

Quiñones, S., \& Marquez Kiyama, J. (2014). Contra la corriente (against the current): The role of Latino fathers in family-school engagement. School Community Journal, 24(1), 149-176.

Scharrón-del Río, M., \& Aja, A. (2015, December 5). The case for 'Latinx': Why intersectionality is not a choice. Retrieved from http://www. latinorebels.com/2015/12/05/the-case-for-latinx-why-intersectionality-isnot-a- choice/\#sthash.6e7Pzb7M.dpuf

Sheets, R. H. (2005). Diversity pedagogy: Examining the role of culture in the teaching learning process. Boston, MA: Pearson.

Tschannen-Moran, M. (2001). Collaboration and the need for trust. Journal of Educational Administration, 39(4), 308-331.

U.S. Census Bureau. (2010). The foreign-born population in the United States: 2010 [American Community Survey Reports]. Washington, DC: E.M. Grieco, Y.D. Acosta, G. P. de la Cruz, C. Gambino, T. Gryn, L.J. Larsen, E.N. Trevelyan, \& N.P. Walters. Retrieved from https://www2. census.gov/library/publications/2012/acs/acs-19.pdf

Valenzuela, A. (1999). Subtractive schooling: U.S.-Mexican youth and the politics of caring. New York, NY: Teachers College Press.

Villalba, J. A., Brunelli, M., Lewis, L., \& Orfanedes, D. (2007). Experiences of Latino children attending rural elementary schools in the Southeastern U.S.: Perspectives from Latino parents in burgeoning Latino communities. Professional School Counseling, 10(5), 506-509.

Zentella, A. C. (2005). Building on strength: Language and literacy in Latino families and Communities. New York, NY: Teachers College Press. 


\section{Author Contact}

Dr. Ingrid Colón: ingrid.t.colon@gmail.com

Dr. Marlon James: mjames1@tamu.edu

Texas A\&M University, College of Education and Human Development, 4232 TAMU, College Station, TX, 7784-4232

Mahjabin Chowdhury: mahjabin@tamu.edu

Texas A\&M University, College of Education and Human Development, 4232 TAMU, College Station, TX, 7784-4232

Dr. Amy Rector-Aranda: aranda@tamu.edu

Texas A\&M University, College of Education and Human Development, 4232 TAMU, College Station, TX, 7784-4232

Dr. Miguel Burgess Monroy: mickey.burgess@tamu.edu

Texas A\&M University, College of Education and Human Development, 4232 TAMU, College Station, TX, 7784-4232 